Vol. 2, No. 1, 2020

https://doi.org/10.23939/jtbp2020.01.081

Oksana Matsiyevska, Iryna Kachmar, Vladyslav Kapitula

\title{
EFFICIENCY OF IRON REMOVAL FROM DRINKING WATER WITH HOUSEHOLD FILTERS
}

\author{
Department of Hydraulic and Water Engineering, \\ Lviv Polytechnic National University \\ oksanamatsiyevska@gmail.com
}

(C) Matsiyevska O., Kachmar I., Kapitula V., 2020

The concentration of total iron is one of the main physicochemical indicators of the safety and quality of tap water. The standard amount of the concentration of common iron in tap water is not more than $0.2 \mathrm{mg} / \mathrm{dm}^{3}$. In some cases, due to specific natural conditions and technology for drinking water preparation/treatment, this number may be increased to $1.0 \mathrm{mg} / \mathrm{dm}^{3}$. Excess iron concentration in the water adversely affects the skin, blood composition, etc. Prolonged consumption of water with high iron concentration leads to liver disease, causes allergic reactions, etc. The analysis of groundwater quality in the territory of the Lviv region shows the increased total iron concentration in water of some water intakes. However, even relatively normal spring water quality and satisfactory operation of pipe water treatment plants, cannot prevent it from secondary pollution in the distribution networks of the water supply system. The Residents of Ukraine use household filters for additional purification of drinking water, including cartridge type. The purpose of the study was to compare the effectiveness of the iron removal from drinking water with household filters of the brands Nasha Voda (Ukraine), BRITA (Germany) and Aquafor (Russia). An experimental research of the filters was performed to determine the dependence of the iron concentration in the filtrate on the volume of the filtered model solution. During the preparation of the model solution, water was used from the water supply system of the city of Lviv, selected in the area of S. Bandera street with a starting iron concentration amount of $0.02-0.3 \mathrm{mg} / \mathrm{dm}^{3}$. After being passed through $15,15 \mathrm{and}^{2.5} \mathrm{dm}^{3}$ of the filtrate, for the filters Nasha Voda, BRITA and Aquafor respectively in the beginning of the experiment, the concentration of iron in the filtrate decreased and reached the normative value of $0.2 \mathrm{mg} / \mathrm{dm}^{3}$. The filtrate volumes passed through Our Water, Nasha Voda, BRITA and Aquafor filters were 210,350 and $80 \mathrm{dm}^{3}$ respectively. The slow filtration rate of the water through the Aquafor filter made it impossible to carry out the experiment after filtering $80 \mathrm{dm}^{3}$ of the model solution. Tested filters have shown positive results in reducing the total iron concentration in water. However, it is recommended to apply the known methods of ironing on water treatment plants of settlements for iron removal from drinking water, particularly from tap water.

Key words: drinking water, general iron, household filters, distribution networks, water supply

\section{Introduction}

The normal functioning of the human body is highly dependent on the stability of its chemical composition. Fluctuations in the amount content of chemical elements in the body, whether excessive or insufficient, leads to a number of diseases. Chemical elements enter the human body mainly with plant and animal food and drinking water (Borzunova, Kuzmin \& Akramov, 2007; Ivanov, Tafeyeva \& Davletova, 2012; Mokiienko, 2015; Omarova, Tussupova, \& Berndtsson, 2017; Shovkun \& Shovkun, 2018; Stepanenkov, 2015; Volkova \& Kushniruk, 2012).

The role of water in human life is extremely important. Water is the most important component of all cells, the basis of intercellular fluid, plasma and lymph; it is about $65-70 \%$ of the body weight. In cells, water is a solvent of inorganic and organic compounds, a participant of many chemical reactions 
that occur in aqueous solutions. Daily rate amount of water consumption consumed by a person is 2.5-3.0 $\mathrm{dm}^{3}$. Depending on the environmental conditions, this rate amount may vary.

The concentration of total iron is one of the main physicochemical indicators of the safety and quality of tap water (Prokopov, 2012).

The standard value of the concentration of total iron in tap water is not more than $0.2 \mathrm{mg} / \mathrm{dm}^{3}$. In some cases, due to specific natural conditions and technology drinking water preparation, this index may be increased to $1.0 \mathrm{mg} / \mathrm{dm}^{3}$.

Water containing iron in large quantities has a yellowish-brown color, increased turbidity, a ferruginous taste, and the like. Water with an iron concentration of more than $0.3 \mathrm{mg} / \mathrm{dm}^{3}$ causes the formation of rusty stains on plumbing fixtures, capable of changing the fabric color during washing, etc.

With significant concentrations of this element in water, a characteristic metallic taste occurs, which negatively affects the quality of the beverages (tea, coffee, etc.). In some cases, the taste and quality of foods cooked on high-iron water may be impaired.

Excess iron concentration in water adversely affects the skin, blood composition and the like. Prolonged consumption of water with high iron concentration leads to liver disease, causes allergic reactions, etc.

\section{Analysis of recent researches and publications}

The analysis of groundwater quality in the territory of Lviv region shows the increased content of total iron in the water of some water intakes. According to the KP "Chervonogradvodokanal", the water intake of the Chervonograd groundwater field does not meet the requirements DSanPiN 2.2.4-171-10 "Hygiene requirements to drinking water intended for human consumption" for iron concentration. During September-October 2010 amount of iron was as follows: Bendyuz water intake $0.32-0.60 \mathrm{mg} / \mathrm{dm}^{3}$; Pravdynskiy water intake $-<0.05-0.56 \mathrm{mg} / \mathrm{dm}^{3}$; Mezhyrychanskiy water intake $0.24-0.40 \mathrm{mg} / \mathrm{dm}^{3}$. Sometimes this concentration reaches more than $1 \mathrm{mg} / \mathrm{dm}^{3}$, which causes human complaints (Stavytskyi, Rudko \& Yakovlev, 2011).

However, even relatively normal spring water quality and satisfactory operation of pipe water treatment plants cannot prevent it from secondary pollution in the distribution networks of the water supply system (Matsiyevska, 2013; Matsiyevska, 2015; Mika, Sekuła, \& Dendys, 2018; Ponomarenko \& Korshun, 2014; Safranov, Polishchuk \& Yurchenko, 2016; Zorina, 2018).

Recently, the residents of Ukraine has been using various household filters, for additional purification of drinking water, including cartridge type. Filters of different productions are presented on the Ukrainian market (Matsiyevska, Dolinska \& Shevchuk, 2009). They all have the following advantages over other water treatment systems:

- no connection to the water supply;

- compactness. They can be used both in the city apartment and in the country;

- versatility. Depending on the type of replacement cartridge, tap water can be effectively softened, de-ironed, removes organic and chlorine derivatives, radionuclides, dioxins, etc.;

- easy maintenance and easy replacement of the cartridge.

The most popular filters in Ukraine are those with replaceable cartridges Nasha Voda (Ukraine), BRITA (Germany), Aquafor (Russia).

The manufacturers of household filters in their passports indicate the filter source and the degree of water purification for some pollutants, such as chlorine derivatives, phenols, heavy metals, etc. However, manufacturers often do not report the effectiveness of the removal of these contaminants over time. Therefore, it is important to compare the efficiency of iron removal from drinking water with household filters of different production. 


\section{Target of this article}

The purpose of the study was to compare the effectiveness of the iron removal from drinking water with household filters-jug brands Nasha Voda (Ukraine), BRITA (Germany) and Akvafor (Russia).

\section{Techniques used}

Fig. 1 shows the appearance of household filters with replaceable cartridges of the brands Nasha Voda (Ukraine), BRITA (Germany) and Aquafor (Russia).

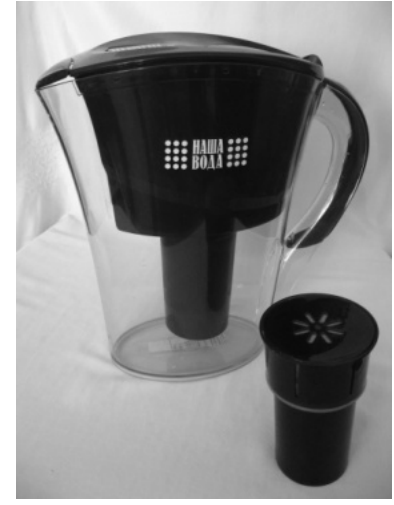

$a$

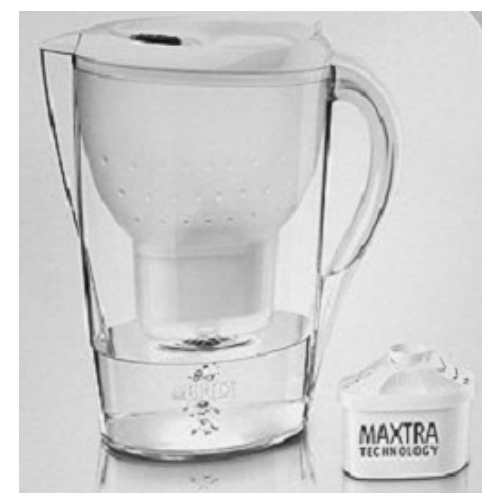

$b$

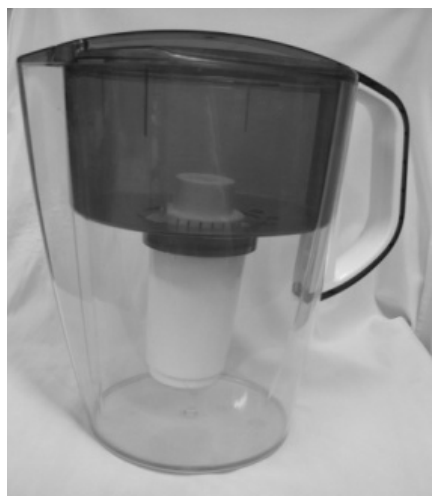

$c$

Fig. 1. Appearance of filter jars with removable branded cartridges: a-Nasha Voda (Ukraine); b-BRITA (Germany); c-Aquafor (Russia)

According to the manufacturer data, the filters produced by Nasha Voda use a replaceable cartridge ECOSOFT KSP MINI. Water purification technology is as follows:

- activated carbon from the coconut shell with the addition of a silver-containing component removes chlorine, organochlorine compounds, and also prevents the reproduction of microorganisms (Fig. 2a);

- the ion exchange resin reduces the mineralization and therefore the hardness of the water. At this stage, heavy and non-ferrous metals and radionuclides are also removed from the water (Fig. 2a);

- polymeric sorption material removes organic compounds, aluminum and residual iron;

- highly efficient activated carbon with a special porous structure removes natural organic compounds, improves the taste, smell and color of purified water;

- porous polypropylene fiber removes mechanical impurities.

The life of the cartridge is no more than 3 months, regardless the volume of purified water. Resource cartridge - up to $400 \mathrm{dm}^{3}$.

BRITA Maxtra filter jug cartridge is BRITA's latest know-how in Germany. Water purification system in BRITA Maxtra cartridge - goes through 4 stages:

- intensive pre-filtration through a fine mesh makes it possible to retain large mechanical impurities;

- ion-exchange resin in H-form softens water, removes aluminum, heavy metals (including copper, lead, etc.) (Fig. 2b);

- activated carbon retains chlorine compounds and other organic impurities, while impregnated silver adds bactericidal properties to the filter (Fig. 2b);

- intensive final filtration through a special fine mesh to remove large impurities.

The cartridge provides flow rate control. Resource cartridge is up to $250 \mathrm{dm}^{3}$.

The cartridge for the Aquafor filter consists of granular and fibrous sorbents (coconut activated carbon, ion exchange resin and Aqualen fibers) (Fig. 2c). It should be noted that only Aquafor filters use unique Aqualen fibers, they are designed specially for drinking water treatment and patented in both Russia and the USA. Due to the high hydrophilic properties of the Aqualen fibers, the water flow is 
uniformly distributed in the dense sorption layer of the cartridge, eliminating the "channel" effects (water flow bypassing the sorbent), providing efficient water purification. The replaceable B100-5 cartridge reliably and permanently retains organic compounds, heavy metals and other harmful impurities and eliminates excessive water hardness. Hardness salts are removed by ion exchange in ion exchange resin granules. Calcium and magnesium cations are delayed and safe sodium and hydrogen cations enter the water. The content of ion exchange resin in the cartridge is adjusted so that the $\mathrm{pH}$ of the drinking water does not change significantly. In order to prevent bacterial development, a modification of Aqualen fiber containing silver fixed in the sorbent matrix is used. Cartridge usually lasts about 2 months in a family of three. Resource cartridge - is $300 \mathrm{dm}^{3}$.

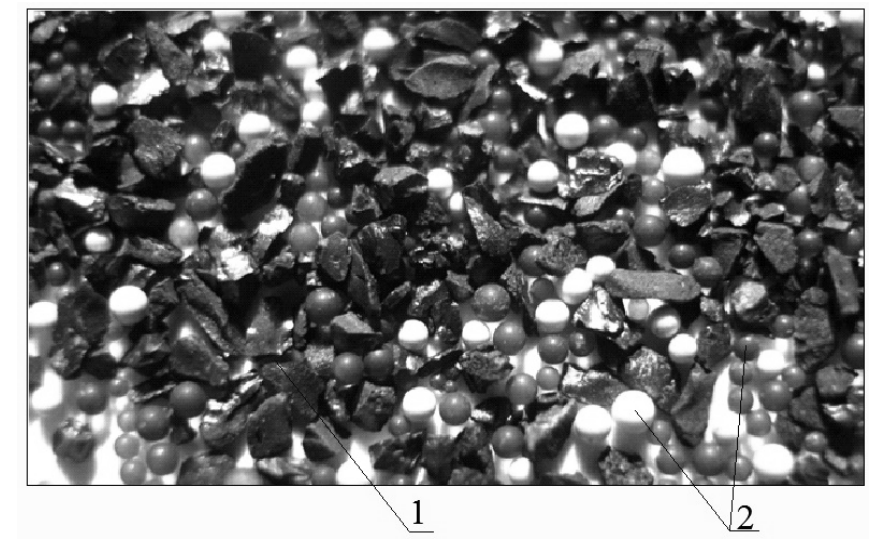

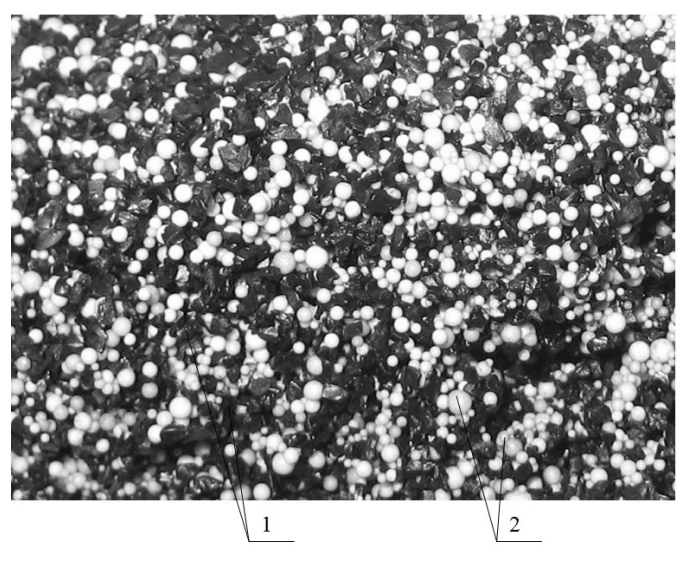

$b$

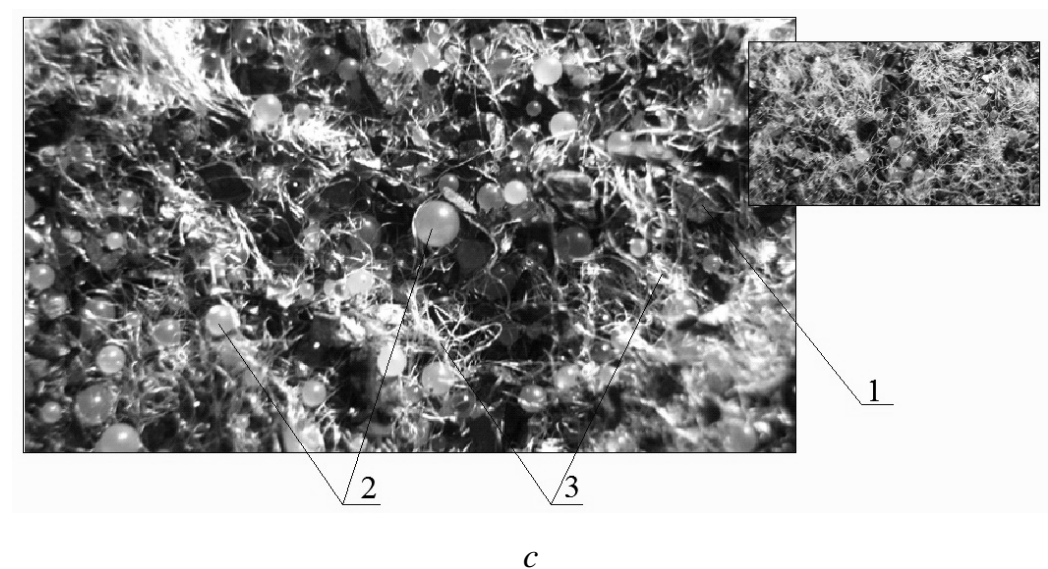

Fig. 2. Filtration loading of cartridges for filters Nasha Voda (a); BRITA (b); Aquafor (c): 1 - activated carbon; 2 - ion exchange resin; 3 - Aqualen fibers

An experimental research of the filters was performed to determine the dependence of the iron concentration in the filtrate on the volume of the filtered model solution. During the preparation of the model solution, water was used from the water supply system of the city of Lviv, selected in the area of the S. Bandera street with a starting iron amount of $0.02-0.3 \mathrm{mg} / \mathrm{dm}^{3}$. The concentration of iron in the model solution was $1 \mathrm{mg} / \mathrm{dm}^{3}$.

During the experiment, $1 \mathrm{dm}^{3}$ of the model solution was poured into the receiving funnel of the filter jug. Flowing through the filter cartridge loading, water went into the tank to collect the filtrate. The concentration of total iron was determined in the filtrate by a GOST 4011-72 "Drinking water. Methods for determination of total iron".

After being passed through 15, 15 and $2.5 \mathrm{dm}^{3}$ of the filtrate, for the filters Nasha Voda, BRITA and Aquafor respectively in the beginning of the experiment, the concentration of iron in the filtrate decreased and reached the normative value of $0.2 \mathrm{mg} / \mathrm{dm}^{3}$ (Fig. 3).

The filtrate volume passed through Nasha Voda, BRITA and Aquafor filters was 210, 350 and 
$80 \mathrm{dm}^{3}$ respectively. The slow filtration rate of the water through filters produced by Aquafor made it impossible to carry out the experiment after filtering $80 \mathrm{dm}^{3}$ of the model solution. The operation of the filters was examined in a continuous mode. Before continuing the operation of the filters, their cartridges had been washed, which may explain the fluctuations in the iron concentration (above the regulatory value) in the filtrate during the filter cycle.

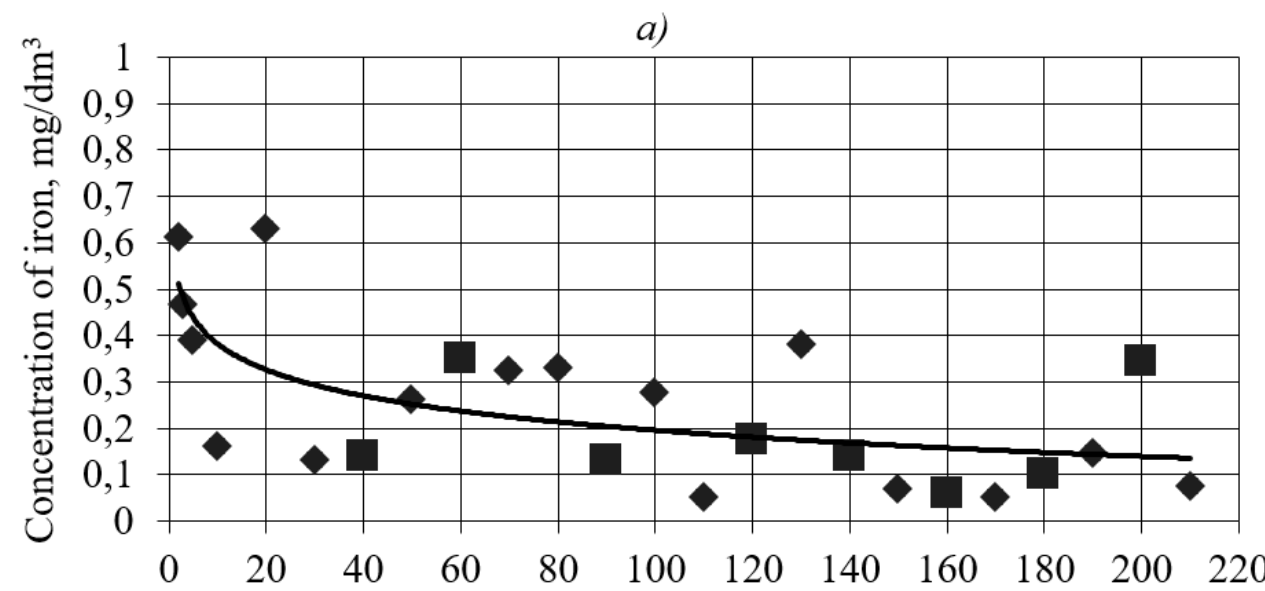

Filtrate volume, $\mathrm{dm}^{3}$
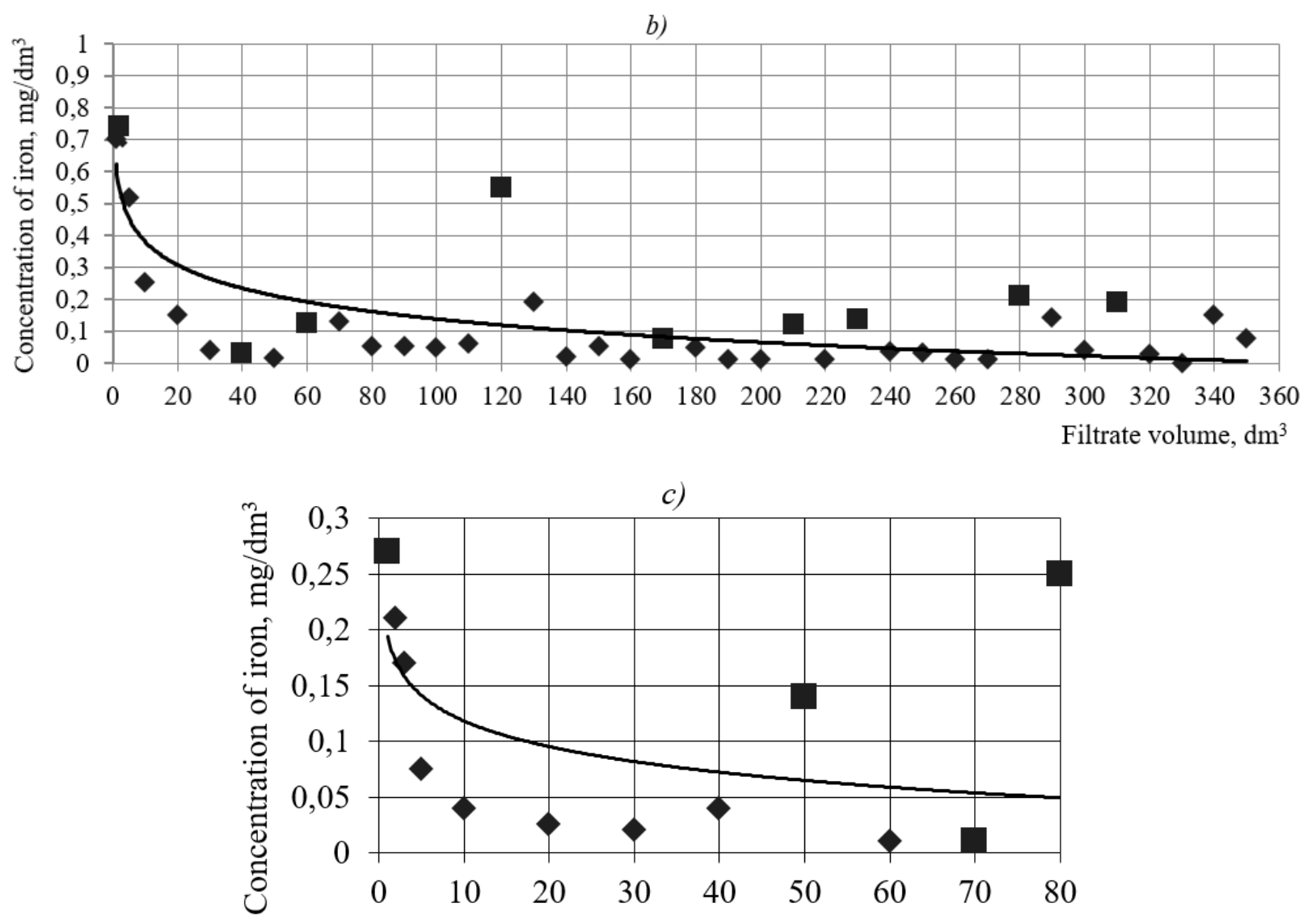

Filtrate volume, $\mathrm{dm}^{3}$

Fig. 3. Dependence of the iron content of the filtrate on the volume of the filtered model solution through the Nasha Voda filter (a), BRITA (b) and Aquafor (c) 


\section{Conclusions}

1. The investigated filters of the brands Nasha Voda (Ukraine), BRITA (Germany) and Aquafor (Russia) showed positive results in reducing the concentration of total iron in water.

2. However, the use of known methods of de-ironing on water treatment plants of inhabited localities should be used for the iron removal from drinking water particularly tap water.

\section{References}

Borzunova, E. A., Kuzmin, S.V., Akramov, R.L., \& Kiyamova, E.L. (2007). Assessment of the impact of water quality on public health. Hygiene and sanitation, 3, 32-34 (in Russian).

Ivanov, A. V., Tafeyeva, Ye. A., Davletova, N. Kh., \& Vavashkin, K. V. (2012). Modern ideas about the impact of drinking water quality on public health. Chemistry and Ecology, 3, 48-53 (in Russian).

Mokiienko, A. V. (2015). Mineralnyi sklad pytnykh ta mineralnykh vod yak faktor vplyvu na zdorovia naselennia (ohliad literatury). Voda: gigiena i ekologiya, 3 (1-2), 50-60 (in Ukrainian).

Omarova, A. O., Tussupova, K. M., Berndtsson, R., \& Kalishev, M.G. (2017). Medical and social significance of water supply, sanitation and hygiene in human activity. Vestnik KazNMY, (Vol. 3, pp. 193-197).

Shovkun, T., \& Shovkun, I. (2018). Yakist pytnoi vody ta yii vplyv na stan zdorovia naselennia Chernihivskoi oblasti. Nauk. zap. Ternop. nats. ped. un-tu im. V. Hnatiuka. Ser. Heohrafiia, 1, 167-173 (in Ukrainian).

Stepanenkov, H. V. (2015). Vplyv yakosti pytnoi vody na stan zdorovia naselennia Poltavskoi oblasti v 2001-2012 rokakh. Visnyk Poltavskoi derzhavnoi ahrarnoi akademii, (1-2), 160-164 (in Ukrainian). https://doi.org/10.31210/visnyk2015.1-2.36.

Volkova, L. A., \& Kushniruk, Yu. S. (2012). Yakist pytnoi vody yak pokaznyk medyko-ekolohichnoho ryzyku terytorii. Heohrafiia ta turyzm, 19, 316-323 (in Ukrainian).

Prokopov, V. O. (2012). Otsinka yakosti pytnoi vody z pidzemnykh vododzherel Ukrainy z pohliadu vplyvu na stan zdorovia naselennia. Naukovyi visnyk Natsionalnoho medychnoho universytetu imeni O. O. Bohomoltsia, 4, 122-126 (in Ukrainian).

Stavytskyi, E. A., Rudko, G. I., \& Yakovlev, Ye. O. (Eds.). (2011). Strategy of drinking groundwater resources use for water supply (Vol. 2). Chernivtsi: Bukrek (in Ukrainian).

Matsiyevska, O. O. (2013). Yakist pytnoi vody, shcho nadkhodyt u merezhu tsentralizovanoho vodopostachannia m. Lviv. Kharchova nauka i tekhnolohiia, 1 (22), 87-89 (in Ukrainian).

Matsiyevska, O. O. (2015). Study of water quality in the distribution network of the centralized water supply system in the city of Lviv. Eastern-European Journal of Enterprise Technologies, 6(6), 62-70 (in Ukrainian). https://doi.org/10.15587/1729-4061.2015.56225.

Mika, A., Sekuła, K., Dendys, M., Ptaszek, W., \& Postawa, A. (2018). Drinking of tap water is smart, but how do it better? - A tap water quality research. E3S Web Conf., Wastewater and Energy in Smart Cities, 30, 01007. https://doi.org/10.1051/e3sconf/20183001007.

Ponomarenko, N. P., \& Korshun, M. M. (2014). Otsinka yakosti hospodarsko-pytnoho vodopostachannia raioniv Chernihivskoi oblasti. Aktualni problemy suchasnoi medytsyny. 14(2), 37-43 (in Ukrainian).

Safranov, T., Polishchuk, A., Yurchenko, V., \& Yaryshkina, L. (2016). Otsinka optymalnosti mineralnoho skladu pytnykh vod system tsentralizovanoho vodopostachannia okremykh miskykh ahlomeratsii Ukrainy. Visnyk Kharkivskoho natsionalnoho universytetu imeni V. N. Karazina seriia "Ekolohiia", (15), $89-98$ (in Ukrainian).

Zorina, O. V. (2018). Hihiienichna otsinka yakosti vodoprovidnykh pytnykh vod za sanitarno-khimichnymy pokaznykamy u malovodnykh rehionakh Ukrainy. ScienceRise. Biological science, 3, 33-39 (in Ukrainian). doi:10.15587/2519-8025.2018.135625.

Matsiyevska, O. O., Dolinska, N. V., \& Shevchuk I. Z. (2009). Eksperymentalne porivniannia roboty filtriv dlia pomiakshennia vody kartrydzhnoho typu. Visnyk Natsionalnoho universytetu "Lvivska politekhnika": Teoriia i praktyka budivnytstva, 655, 178-182 (in Ukrainian). http://ena.lp.edu.ua:8080/handle/ntb/2923. 
О. О. Мацісвська, І. 3. Качмар, В. В. Капітула Національний університет “Львівська політехніка", кафедра гідротехніки та водної інженерії

\title{
МОДЕЛЮВАННЯ СОНЯЧНИХ ТЕПЛОНАДХОДЖЕНЬ ВІД СИСТЕМ ПРОРОДНОГО ОСВІТЛЕННЯ СКЛАДНОЇ ГЕОМЕТРІЇ
}

\author{
(C) Мацієвська О. О., Качмар I. 3, Капітула В. В., 2020
}

Значення концентрації загального заліза - одне 3 головних фізико-хімічних показників безпечності та якості водопровідної води. Нормативне значення концентрації загального заліза у водопровідній воді - не більше за 0,2 мг/дм³. В окремих випадках, пов'язаних з особливими природними умовами та технологією підготовки питної води, цей показник може бути збільшений до 1,0 мг/дм³ ${ }^{3}$. Надлишковий вміст заліза у воді несприятливо впливає на шкіру, склад крові тощо. Тривале споживання води з підвищеним вмістом заліза призводить до захворювань печінки, викликає алергічні реакції тощо. Аналіз якості підземних вод на території Львівської області свідчить про підвищений вміст загального заліза у воді деяких водозаборів. Проте, навіть за відповідної якості води в джерелах та задовільної роботи водопровідних очисних споруд не виключене ії вторинне забруднення у розподільних мережах системи водопостачання населених пунктів. Населення України для додаткового очищення питної води використовує побутові фільтри, зокрема картриджного типу. Мета дослідження - порівняння ефективності знезалізнення питної води побутовими фільтрами марок “Наша вода” (Україна), BRITA (Німеччина) та “Аквафор” (Росія). Експериментальне дослідження роботи фільтрів виконували для визначення залежності вмісту заліза у фільтраті від об’ єму профільтрованого модельного розчину. Під час приготування модельного розчину використовували воду з водопроводу м. Львова, відібрану в районі вул. С. Бандери з вихідним вмістом заліза 0,020,3 мг/дм³ ${ }^{3}$ Концентрація заліза у модельному розчині становила 1 мг/дм³. 3 початку експерименту концентрація заліза у фільтраті зменшувалась і досягала нормативного значення 0,2 мг/дм після проходження 15, 15 та 2,5 дм³ фільтрату відповідно для фільтрів “Наша вода”, BRITA та “Аквафор”. Об'єм фільтрату, який пройшов крізь фільтри “Наша вода”, BRITA та “Аквафор”, становив

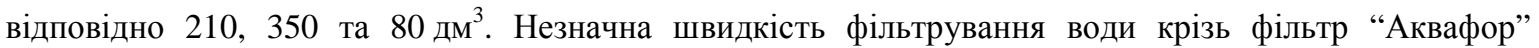

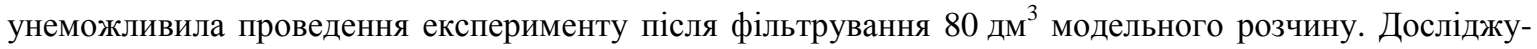
вані фільтри показали позитивні результати щодо зменшення вмісту загального заліза у воді. Проте, для знезалізнення питної води (зокрема водопровідної) варто застосовувати відомі методи знезалізнення на водопровідних очисних спорудах населених пунктів.

Ключові слова: питна вода, залізо загальне, побутові фільтри, розподільні мережі, система водопостачання 